\title{
Consolidation for Desegregation: The Unresolved Issue of the Inevitable Sequel
}

In a rare moment of equipoise, the United States Supreme Court on May 21, 1973, in Bradley v. School Board [Richmond] ${ }^{1}$ ended twelve years of school desegregation litigation in Richmond, Virginia, by refusing to reinstate a court-ordered consolidation of city and suburban school divisions. By dividing equally, however, the eight-man Court" proffered no opinion in the case termed an "inevitable sequel" 3 to Brown v. Board of Education [Brown I].* Its affirmance is conclusive and binding on the parties to the Richmond suit, ${ }^{5}$ and the court of appeals opinion is controlling in the Fourth Circuit. The Supreme Court's action, however, is not an authoritative precedent outside that circuit. ${ }^{6}$

In addition to its lack of direct precedential authority, the court of appeals opinion in Richmond is flawed by its confusion of the existence of a constitutional violation with the determination of the appropriate scope of a remedial decree. ${ }^{7}$ The underlying issues of school desegregation in metropolitan areas composed of more than one political subdivision thus remain unresolved.

Moreover Richmond was only one of a number of suits seeking consolidation of city and suburban school divisions. ${ }^{8}$ The Sixth Cir-

1. 338 F. Supp. 67 (E.D. Va.), rev'd, 462 F.2d 1058 (4th Cir. 1972), aff'd per curiam by an equally divided Court, 93 S. Ct. 1952 (1973).

2. Mr. Justice Powell took no part in the consideration or decision. 93 S. Ct. 1952 (1973). He had previously disqualified himself because of prior membership on the Richmond School Board, one of the petitioners, and on the Virginia State Bourd of Education, one of the defendants. N.Y. Times, May 22, 1973, at 1, col. 5.

3. The phrase was used by Solicitor General Erwin N. Griswold in the oral argument of Richmond before the Court. 41 U.S.L.W. 3577, 3579 (U.S. Apr. 23, 1973).

4. 347 U.S. 483 (1954) [Brown I] and 349 U.S. 294 (1955) [Brow'I II].

5. United States v. Pink, 315 U.S. 203, 216 (1942). On June 15, 1973, attorneys for the Richmond plaintiffs did, however, file a petition for rehearing. The Richmond School Board filed its petition for rehearing on July $14,1973$.

6. Id. See generally iB J. MOORE, FEDERAL Practice $9.402[2]$, al 119 (2d ed. 196j).

7. See pp. 1683-84 infra.

8. Besides Richmond, the two most advanced consolidation cases involve descgregation in Detroit and Indianapolis. The district court opinion in the Detroit case, Bradley $v$. Milliken [Detroit], is embodied in four rulings and findings: Ruling on Issue of Segregation, the primary opinion dated September 27, 1971, 338 F. Supp. 582 (E.D. Mich. 1971); Ruling on Propriety of Considering a Mctropolitan Remedy to Accomplish Desegregation of the Public Schools of the City of Detroit, C.i. No. 35257 (E.D. Mich. March 24, 1972); Findings of Fact and Conclusions of Law on Detroit-Only Hlans of Desegregation, C.A. No. 35257 (E.D. Mich. March 28, 1972); and Rulings on Desegregation Area and Order for Development of Plan of Desegregation, June 14, 1972, 345 F. Supp. 914 (E.D. Mich. 1972). The Court of Appeals for the Sixth Circuit, by a 6.3 margin, 
cuit's June 12, 1973, decision in Bradley v. Milliken [Detroit] $]^{0}$ emphasizes, despite the current equipoise at the Supreme Court level, the need for reexamination of the relationship of duties and obligations of state and local school officials. This Note will argue that the affirmative duty to desegregate must be placed where the Constitution places it: upon the state.

\section{The Requirement of a Constitutional Violation}

The starting point for any school desegregation case is the Equal Protection Clause of the Fourteenth Amendment. ${ }^{10}$ The crucial trigger for traditional Fourteenth Amendment cases"11 is official or "state action" causing deprivation of equal protection of the laws. ${ }^{12}$ In the three leading consolidation cases, Bradley v. School Board [Richmond], Bradley v. Milliken [Detroit] and United States v. Board of School Commissioners [Indianapolis], ${ }^{13}$ the trial courts made findings clearly

affirmed en banc the September 1971 Ruling on Issue of Segregation and the March 28, 1972, Findings, but vacated the other two decisions as well as an order dated July 11, 1972, directing purchase of 295 school buses, and remanded the case to the district court. Detroit, Nos. 72-1809-72-1814 (6th Cir. June 12, 1973). The court of appeals decision reaches the same result as the vacated opinion of a Sixth Circuit panel filed December 8, 1972. Chief Judge Phillips wrote the majority opinion in the June 12, 1973, decision and the only opinion in the vacated decision.

The Indianapolis case, United States v. Board of School Comm'rs [Indianapolis], 332 F. Supp. 655 (S.D. Ind. 1971), aff'd, 474 F.2d 81 (7th Cir. 1973), has itself had an ex tended procedural history. The School Town of Speedway, onc of the areas potentially in. volved in the consolidated school district, sought a writ of prohibition which was denied by the Seventh Circuit and ultimately by the Supreme Court. School Town of Specdway v. Dillin, 407 U.S. 920 (1972).

Metropolitan remedies are also under consideration in other arcas. See, e.g., Calhoun v. Cook, 332 F. Supp. 804, 809 (5th Cir. 1971), which deals with the continuing desegregation of the Atlanta public schools. The issue is also involved in suits filed in Boston, Buffalo, Dayton, Durham, N.C., Grand Rapids, Mich., Hartford, Louisville, and Wil. mington. N.Y. Times, May 27, 1973, $\$ 4$, at 3, col. 2. Earlier decisions bearing on the metropolitan consolidation remedy include Haney v. County School Bd. of Educ. (W.D. Ark. 1968), rev'd and remanded, 410 F.2d 920 (8th Cir. 1969), Order filed Aug. 7, 1969 (W.D. Ark.), vacated and remanded, 429 F.2d 364 (8th Cir. 1970) (a Negro school district within a county ordered consolidated with the rest of the county); Harrington v. Col. quitt County Bd. of Educ., 460 F.2d 193 (5th Cir. 1972) (five predominantly white ele. mentary schools outside the city of Moultrie, Georgia, included within the city school district); United States v. Texas, 321 F. Supp. 1043 (E.D. Tex. 1970), aff'd as modified and remanded, 447 F.2d 441 (5th Cir. 1971), cert. denied sub nom. Edgar v. United States, 404 U.S. 1016 (1972) (state educational authorities required to come forward with desegregation plans that included alteration of independent district boundaries where required)

9. Detroit, Nos. 72-1809-72-1814 (6th Cir. June 12, 1973).

10. "No State shall make or enforce any law ... nor deny to any person within its jurisdiction the equal protection of the laws." U.S. Consr. amend. XIV $\$ 1$.

11. See, e.g., Shelley v. Kraemer, 334 U.S. 1, 13 (1948).

12. See Swann v. Charlotte-Mecklenburg Bd. of Educ., 402 U.S. 1, 16 (1971).

13. Bradley v. School Bd., 338 F. Supp. 67 (E.D. Va.), rev'd, 462 F.2d 1058 (4th Cir. 1972), aff'd by an equally divided Court, 93 S. Ct. 1952 (1973); Bradley v. M(illiken, 998 F. Supp. 582 (E.D. Mich. 1971), aff'd, Nos. 72-1809-72-1814 (6th Cir. June 12, 1979); United 
establishing constitutional violations. ${ }^{14}$ Although these violations were independent of the establishment and maintenance of interdistrict boundaries, they included proscribed activities at both the local and the state level. ${ }^{15}$

The general category of constitutional violation which each district court sought to eliminate was the continued racial identifiability ${ }^{10}$ of schools and school divisions within a single metropolitan area ${ }^{17}$ resulting from past and present discriminatory official acts. It was in failing to affirm the district court's findings of constitutional violation that the Fourth Circuit in Richmond utilized an improper test. The majority there emphasized the absence of any finding of "joint interaction" between any of the political subdivisions for the purpose of keeping one unit relatively white by confining blacks to another. ${ }^{18}$ Closely linked to this emphasis was the conclusion that only a "constitutional violation in the establishment and maintenance of these three school districts"19 would justify the remedy of consolidation. But although the majority found no joint interaction, it did specifically approve the district court findings that all three municipalities committed numerous acts of discrimination, ${ }^{20}$ and that each formerly operated a dual system of schools. ${ }^{21}$ Moreover, the court of appeals

States v. Board of School Comm'rs, 332 F. Supp. 655 (S.D. Ind. 1971), af/d, 474 F.2d 81 (7th Cir. 1973); see notes I and 8 supra. These three localities have broadly differing back. grounds of official conduct respecting racial segregation. In Virginia, ncial segregation in all areas of life, and most particularly in public schools, was cnforced by state statute, VA. CODE $\$ 22-221$ (1950, repealed 1971), and the state constitution, VA. CoNsr. \$ 140 (repealed $1971)$, at least until 1954 . Indiana, although it had a history of segregation, required desegregation on a phased basis by statute enacted in 1949. Acrs 1949, ch. 180, at 603: Bunis IND. STAT. ANN. \$\$ 28-6106 to 28.6112 (1970), as amended, IND. CODE \$\$ 20-4.1-7 to 20.4-1-13 (1971). Thus Indiana officially outlawed segregation some five years prior to Broun $l$. Michigan, by contrast, never required, or by statute permitted, racial segregation in schools or other public facilities.

14. The specific findings are discussed pp. $1684-86$ infra.

15. See pp. 1685-86 infra. In Indianapolis, the state officials viere added as parties to the suit after the filing of the district court opinion. Nevertheless, the court alluded to potential state violations, $332 \mathrm{~F}$. Supp. at 675 passim and 679 , and directed service of process on the attorney general of Indiana. Id. at 680 .

16. The Richmond district court opinion is replete with references to "racially identifiable" schools. Richmond, $338 \mathrm{~F}$. Supp. 67 passim. The district judge termed it "both a legal concept-a conclusion of law, ultimately-and a fact of major significance to cdu. cators and lay persons." Id. at 80 . Generally, racial identifiability is "a perception of students, faculty and community perception" that certain schools or districts are black "while others are white." Id.

17. This underlying unity of the metropolitan area is crucial to the Richmond district court opinion. See, e.g., the reference to "a bi-racial community," id. at 80 (cmphasis added), to the "historic flexibility" and "cooperative operation" between the localities, id. at 100 , and the stable racial proportions within "the three jurisdictions together." id. at 185. See also note 102 infra.

18. Richmond, 462 F.2d at 1065.

19. Id. at 1069 (emphasis added).

20. Id. at 1065, 1066 .

2I. Id. at 1065 . 
did not specifically disapprove any other findings of the district court. What it did conclude, in contradiction to the admissions of the Richmond School Board and its own previously-noted approval of the district court findings, was that "the last vestiges of state-imposed segregation have been wiped out ..." and that therefore "there is no constitutional violation ...."22 This conclusion could only be reached by equating "constitutional violation" with "joint interaction," an equation that improperly requires a finding of an illegal purpose or motivation rather than a forbidden effect. ${ }^{23}$

The Sixth Circuit implicitly rejected this equation in Detroit. Although the majority opinion made a point of distinguishing its holding from that of the Fourth Circuit's opinion in Richmond, ${ }^{24}$ its conclusion that the district court was not confined to the boundary lines of the city in fashioning equitable relief ${ }^{25}$ is directly contradictory to the Richmond holding. ${ }^{26}$

In elaborating on the general constitutional violations, the trial courts in Richmond, Detroit and Indianapolis found and discussed numerous specific acts of discrimination. Each court found that school construction policy ${ }^{2 \tau}$ and transportation of pupils ${ }^{28}$ were widely used to maintain segregated school systems. Local officials with state concurrence selected school construction sites to coincide with patterns of segregated housing, ${ }^{29}$ and reinforced the result by drawing attendance zones to conform to such patterns. ${ }^{30}$ Discriminatory pupil assignment practices often accentuated the resultant segregation. ${ }^{31}$ Rich-

22. Id. at 1070 .

23. See discussion in Wright v. Council of the City of Emporia, 407 U.S. 451, 462 (1972).

24. Detroit, Nos. 72-1809-72-1814 at 66 (6th Cir. June 12, 1973).

25. Id. at 65 .

26. Sce p. 1683 supra.

27. The importance of school construction in desegregation has been recognizcd in numerous cases. See, e.g., Davis v. School Dist., 443 F.2d 573, 576 (6th Gir. 1970), cert. denied, 404 U.S. 913 (1971); Brewer v. School Bd., 397 F.2d 37, 42 (4th Cir. 1968); Unitcd States v. School Dist. 151, 404 F.2d 1125, 1133 (7th Cir. 1968).

28. Transportation, or "busing," has been approved as a descgregation tool. Swann $v$. Charlotte-Mecklenburg Bd. of Educ., 402 U.S. 1, 29-31 (1971).

29. Richmond, 338 F. Supp. at 86.87, 127 passim, 133 passim; Detroit, 338 F. Supp. at 588; Indianapolis, $332 \mathrm{~F}$. Supp. at 668-69.

30. Richmond, 338 F. Supp. at 78; Detroit, 338 F. Supp. at 588, 592.93; Indianapolis, 332 F. Supp. at 667 .

31. Richmond continued to use a "freedom of choice" assignment plan until 1970, Richmond, 317 F. Supp. 555, 557 (E.D. Va. 1970), well after the Supreme Court held such plans to be of questionable effectiveness in Green v. County School Bd., 391 U.S. 320 (1968). Richmond, $338 \mathrm{~F}$. Supp. at 70.

Detroit school officials bolstered their assignment policy by utilizing optional at. tendance zones in transition areas of integrated housing. Detroit, $338 \mathrm{~F}$. Supp. at 587 . Indianapolis also utilized optional attendance zones, 332 F. Supp. at 668.69 , although stich use has been held to violate the Fourteenth Amendment in such cases as Hobson $v$. Hansen, 269 F. Supp. 401 (D.D.C. 1969), aff'd sub nom. Smuck v. Hobson, 408 F.2d 175 (D.C. Cir. 1969), and Spangler v. Pasadena City Bd. of Educ., 311 F. Supp. 501, 502 (C.D.
Cal. 1970). 
mond and Detroit officials engaged in pupil exchanges with suburban divisions ${ }^{32}$ while in Indianapolis, such divisions accepted fleeing city pupils on a tuition basis. ${ }^{33}$

The findings of constitutional violations were not confined to local officials, even though such violations are imputed to the state. ${ }^{34}$ The Richmond and Detroit trial courts made specific findings of violations by the state defendants. ${ }^{35} \mathrm{~A}$ finding that the ultimate responsibility for public education resided in the state and not the local board was the starting point of the inquiry. ${ }^{30}$ Discriminatory school financing in Detroit, ${ }^{37}$ as well as concurrence by Virginia and Michigan officials in discriminatory.construction ${ }^{38}$ and transportation policies, ${ }^{30}$ headed the list of violations specifically attributable to the state.

State statutes in each case directly and indirectly hampered desegregation. Even after the end of Virginia's "massive resistance" to the

32. Richmond, 338 F. Supp. at 157; Detroit, Nos. 72-1809-72-1814 at 28.30 (6th Cir. June 12,1973$)$.

33. Indianapolis, $332 \mathrm{~F}$. Supp. at 667.

34. See pp. 1688-89 infra.

35. State officials were not defendants in the original Richmond litigation. However. on November 4, 1970, the Richmond School Board filed a motion to compel joinder of the state board of education and the individual members thereof and the state superintendent of public instruction, as well as school boards, school officials and boards of supervisors of the surrounding counties. The motion was granted December 5, 1970. Richmond, 51 F.R.D. 139 (1970).

Detroit originally included the governor, attorney general, state board of education and state superintendent of public instruction of the state of Michigan as defendants. The district judge's original order dismissing the governor and attorney general was reversed by the court of appeals. Detroit, 433 F.2d 897,905 (6th Cir. 1970).

The state of Indiana was not a defendant in the original suit which was brought by the United States under $\$ \S 407$ (a) and (b) of the Civil Rights Act of 1904, 42 U.S.C. $\$ \$ 2000 c-6(a) \&-6(b)$ as well as under the Fourteenth Amendment. The Indiana Board of Education and the superintendent of public instruction, as well as seven representative school districts, were joined as defendants, however, after the filing of an amended com. plaint on October 22, 1971.

36. See Richmond, 338 F. Supp. at 93, 116; Detroit, 338 F. Supp. at 593.

37. Detroit, 338 F. Supp. at 589 . Michigan provided state funds for pupil transporta. tion in every school district but Detroit. Id. See also Detroit, Nos. 72-1809-72-1814 at 42, 48 (6th Cir. June 12, 1973). Additionally, until 1969, Michigan limited Detroit's au. thority for capital improvement bonding to two percent of assessed property valuation, while allowing a ceiling of five percent in all other school districts. $338 \mathrm{~F}$. Supp. at 589 .

38. In Virginia, state approval was required prior to beginning construction, and until 1965, the application for state construction funds had to state for which race the school was being constructed. Richmond, 338 F. Supp. at 124-27.

The district court in Detroit found that, although the state board of education had nominally encouraged school site selection as a tool of integration, "[t] he State defendants have similarly failed to take any action to effectuate these policies." $338 \mathrm{~F}$. Supp. at 589.

39. Michigan's involvement in maintaining a dual school system consisted of passive acceptance of interdistrict busing to preserve segregation, Detroit, Nos. 72-1809-72-1814 at 43 (6th Cir. June 12, 1973). See also the vacated opinion of the Sixth Circuit pancl, Detroit, Nos. 72-1809-72-1814 at 27-29, 42 (6th Cir. Dec. 8, 1972). Virginia officials, by contrast, actively supported segregated schools. The district judge alluded to the point by citing four previous cases. Richmond, 338 F. Supp. at 83, ciling Buckner v. County School Bd., 332 F.2d 452 (4th Cir. 1964); School Bd. v. Kilby, 259 F.2d 497 (4th Cir. 1958); Corbin v. County School Bd., 177 F.2d 924 (4th Cir. 1949); Goins v. County School Bd., 186 F. Supp. 753 (W.D. Va. 1960). 
dictates of Brown $I^{40}$ the "purposeful frustration" of the desegregation process $^{41}$ continued. It included a statutory limitation of the state board of education's power to consolidate school divisions during the pendency of the Richmond suit which sought such consolidation. ${ }^{42}$ Likewise, a 1970 enactment of the Michigan legislature ${ }^{43}$ injected the state into the Detroit desegregation process. ${ }^{44}$ In Indianapolis, changes in state statutes consolidated the city and surrounding Marion County in virtually all aspects except schools. ${ }^{45}$

The district courts in the three primary cases did not rule on the sufficiency of any single act to trigger the court's remedial power. Each court did, however, find that the cumulative effect of the local and state actions and inactions violated the Fourteenth Amendment. ${ }^{40}$ The courts of appeals in each case did not question the district judge's findings of fact. ${ }^{47}$

The most unsettled area of the trial court findings concerned residential segregation. Each district court placed particular emphasis on housing pattern. ${ }^{48}$ The Richmond and Detroit district courts found state action violations in this area. ${ }^{40}$ The courts of appeals, however, reached different conclusions about the significance of these findings

40. Virginia statutory and constitutional provisions requiring segregation in public education, VA. CONST. $\$ 140$ (which remained in the constitution, although invalidated, until the new state constitution became effective on July 1, 1971) and VA. CodE ANN. $\$ 22-221$ (which was repealed by [1971] Acts of Assembly, Ex. Sess. c.102), were invalidated by Brown I, 347 U.S. 483 (1954). Richmond, 338 F. Supp. at 138 passim. See generally R. Gates, The Making of Massive Resistance (1962).

41. Richmond, 338 F. Supp. at 94 passim.

42. VA. CODE ANN. $\$ 22-30$ as amended by [1971] Acts of Asscmbly, Ex. Scss., c.225. This amendment restricted the previously unfettered power of the state board of educa. tion to create school divisions composed of more than one political subdivision. Under the current law the state board may act only upon request of the school boards with the concurrence of the governing bodies of the affected school districts.

43. Act No. 48, $\S 12$, [1970] Public Acts of Michigan. The complaint in Detroit, originally filed August 18, 1970, sought to enjoin the defendants from giving force and effect to $\$ 12$. Detroit, 433 F.2d 897 (6th Cir. 1970). The statute by its terms applied "to any first class school district." Detroit, however, was the only first class district in Michi. gan. The court of appeals declared the section unconstitutional as a violation of the Fourteenth Amendment. Id.

44. See Detroit, 338 F. Supp. at 589.

45. Indianapolis, 332 F. Supp. at 675-76. It was the so-called "Uni-Gov" Act which actually brought about this change. Acts of 1969 , ch. 173, at 357 ; BurNs INd. STAT. ANN. $\S \S 48.9101-48.9507$ (1970 Cum. Supp.), IND. CODE $\$ \S 18-4-1-1$ to 18.4-5.4 (1971).

46. - See pp. 1683-86 supra.

47. For discussion of the court of appeals opinion in Richmond, see pp. 1683.81 supra.

In Detroit the district judge's substantive findings on the constitutional violations are contained in the Ruling on the Issue of Segregation, 338 F. Supp. 582 (E.D. Mich. 1971). This ruling was specifically affirmed by the Sixth Circuit's en banc opinion. Detroit, Nos. 72-1809-72-1814 at 80 (6th Cir. June 12, 1973).

The Seventh Circuit affirmed each of the findings of the district court in Indianapolis. Indianapolis, 474 F.2d at 88.

48. See Richmond, 338 F. Supp. at 84, 91-92, 212-29; Detroit, 338 F. Supp. at 586-87; Indianapolis, 332 F. Supp. at 661-63.

49. Richmond, 338 F. Supp. at 92; Detroit, 338 F. Supp. at 587. 
for segregated school patterns. ${ }^{50}$ Although segregated housing and segregated schooling are undoubtedly related, 51 for the purposes of the argument here the former will be considered as a fixed background against which the latter must be alleviated. 52

\section{The State as "Hidden Defendant"}

In the earliest school desegregation cases, where plaintiffs attacked state statutes, the states through various officials were necessarily parties to the suits. ${ }^{53}$ After the Supreme Court invalidated overt statutory segregation and the furor of outright defiance had subsided, 5 t the focus of the desegregation process centered on the local school boards as the federal district courts assumed their roles as overseers of the desegregation process. ${ }^{65}$

Beginning in 1955, and particularly after the movement toward compliance began around 1960, state officials faded from the status of involuntary defendants in desegregation litigation. ${ }^{50}$ This is not to say that they did not appear before courts in desegregation matters;

50. In Richmond the court of appeals let stand some findings on housing discrimination, but it rejected the theory that the counties were kecping blacks in Richmond schools while allowing the whites to flee to relatively white sanctuaries. $462 \mathrm{~F} 2 \mathrm{~d}$ at 1065.

The Sixth Circuit in Detroit did not rely at all upon testimony pertaining to segregated housing except as to whether school construction programs helped cause or maintain such segregation. Detroit, Nos. 72-1809-72-1814 at 50 (6th Cir. June 12, 1973).

The Seventh Circuit upheld the district judge's findings as not clearly erroneous, eren though it recognized that other forces had had a significant impact on residential housing patterns in Indianapolis. Indianapolis, $474 \mathrm{~F} .2 \mathrm{~d}$ at $88-89$.

51. Keyes v. School Dist. No. 1, 313 F. Supp. 61 (D. Colo. 1970), aff'd in part, rev'd in part, 445 F.2d 990 (10th Cir. 1971), aff'd, 41 U.S.L.W'. 5002 (U.S. June 21, 1973), points to the growing trend of erasing the distinction between de facto and de jure segregation that had produced disparate results in the North and in the South. In Keyes the Supreme Court, for the first time, held that actions of school officials producing segregated con. ditions were just as much state action as statutorily required dual schools. Many of the specific practices condemned by the Court in Keyes, particularly school consiruction policies, gerrymandering of attendance zones, and the use of "optional zones," are identical to those identified and condemned in the three primary cases discussed in this Note. See 41 U.S.L.W. at 5002.

52. One commentator on the Richmond case has vicwed the explicit recognition of the interrelationship between school and housing segregation as the major advance made by the case. Comment, Comprehensive Metropolitan Planning: A Reinterpretotion of Equal Educational Opportunity, 67 Nw. U.L. REv. 388 (1972).

53. Brown $I, 347$ U.S. 483 (1954), was a consolidation of suits in four states secking to enjoin the enforcement of state statutes and, in three of the four states, state constitutional provisions requiring segregation by race in public schools. 347 U.S. at 486 n.I.

54. For comprehensive discussion of the years of outright defiance sce B. MfUSE, TEv Years of Prelude 1-209 (1964); A. Lewis \& The New York TiMes, Portmatr of A Decade: The Second AMerican Revolution 3-69 (1962); R. Gates, Tue MAling of Massive REsistance: Virginia's Politics of Public School Desegreatiox, 1954-19j6 (1962).

55. Brown II, 349 U.S. 294 (1955), placed primary responsibility for compliance on the local school authorities but required judicial supervision of the process. $349 \mathrm{US}$. at 299 . The district courts were also charged to retain jurisdiction of the cases. Id. at 301 .

56. See B. MIUSE, supra note 54, at 210. 
rather, such appearances were occasioned by affirmative state interference in the desegregation process ${ }^{57}$ or by the state's voluntary decision to intervene in the litigation. ${ }^{58} \mathrm{Absent}$ direct resistance by the state to desegregation, the obligation to dismantle dual schools fell solely upon local officials and the states were given the opportunity to avoid defendant status in litigation. ${ }^{59}$ Thus, to a large extent, state officials could remain behind the scenes and join the fray only when they chose to do $50 .{ }^{60}$

The consolidation cases have run counter to this trend. Although no state officials were party to the original Richmond suit filed in 1961, the state board of education and state superintendent of public instruction were joined as defendants in December 1970.01 In Detroit, on the other hand, since the original complaint challenged the constitutionality of a 1970 Michigan statute, the governor, attorney general, acting superintendent of public instruction and the state board of education were defendants from the beginning. ${ }^{02}$ Indianapolis followed the Richmond pattern, with the members of the state board of education and the superintendent of public instruction added as defendants following the filing of an amended complaint. ${ }^{03}$ Regard. less of the pattern, at the remedy stage in each case state officials were before the court in defendant status and therefore unquestionably subject to the court's jurisdiction.

\section{Attribution of Violations: The State as Defendant in Fact}

There is no mention of local government in the United States Constitution, which recognizes only the federal government and the states as governing units. ${ }^{64}$ Counties, cities and towns are mere political

57. See, e.g., Lee v. Macon County Bd. of Educ., 267 F. Supp. 458 (M.D. Ala.), aff'd sub nom. Wallace v. United States, 389 U.S. 215 (1967).

58. In Green v. County School Bd., 391 U.S. 430 (1968), no official of the state of Virginia was named as a defendant even though the state policy of "frectom of choice" was being challenged.

59. The administrative process, directed by the United States Office of Education, put considerable pressure on state officials to comply with the 1966 "guidelines." See" gen. erally Civit Rights 1960-66, at 413-16 (L. Sobel ed. 1967).

60. In Swann v. Charlotte-Mecklenburg Bd. of Educ., 402 U.S. 1 (1971), the state of North Carolina was not a defendant and the focus was exclusively on the local school board. In a companion case, however, state officials were the original defendants and a state statute was being challenged. North Carolina State Bd. of Educ. v. Swann, 402 U.S. 43 (1971). Nevertheless, the trend seemed clear that absent regressive action by state all. thorities, the state could escape defendant status in desegregation suits.

61. Richmond, 51 F.R.D. 139 (E.D. Va. 1970).

62. Detroit, 433 F.2d 897, 898 (6th Cir. 1970).

63. The amended complaint was filed October $22,1971$.

64. See Allen v. County School Bd., 207 F. Supp. 349, 354 (E.D. Va. 1962), rev'd sub nom. Griffin v. Board of Supervisors, 332 F.2d 332 (4th Cir. 1963), rev'd and district court opinion reinstated, 337 U.S. 218 (1964). 
subdivisions of the state, created by the state as convenient agencies for exercising governmental power ${ }^{05}$ A state may grant to them or withhold from them powers and privileges as it sees fit. ${ }^{60}$ Since political subdivisions are agencies of the states, officials of these subdivisions are state agents, and their official actions are clearly official action of the state. ${ }^{67}$ This is particularly so in the field of education, where the responsibility of the state is primary. ${ }^{68}$

But if these considerations and the attribution of local actions to state officials establish that the states have always been defendants in desegregation cases, it is only in the metropolitan cases that state officials and agencies ${ }^{60}$ have been charged with affirmative rather than merely negative duties. ${ }^{70}$

The most dramatic effect of such considerations is on the scope of the remedy available. If the violation occurs at the state level and the state is responsible for the violation, then the "affirmative duty" to eliminate discrimination "root and branch" is the duty of state officials, ${ }^{71}$ and not just of the local school board. A failure to discharge this duty gives the court remedial power over state officials. Although the alteration of school division boundaries is arguably beyond the power of officials of any one division, or even of two adjoining divisions, it is certainly within the power of the state. ${ }^{72}$

65. Hunter v. Pittsburgh, 207 U.S. I61, 178 (1907).

66. Trenton v. New Jersey, 262 U.S. 182 (1923). See also .14kin v. Kansas, 191 U.S. 207 (1903).

67. See Cooper v. Aaron, 358 U.S. 1, 16 (1958).

68. See note 36 supra.

69. Preliminarily it may appear that the Eleventh Amendment presents application of the judicial power of the United States against one of the states. U.S. CoNst. amend. XI. This argument, however, has been advanced and rejected in the school desegregation context. Griffin v. County School Bd., 377 U.S. 218, 228 (1964). It was, hoviever, raiscd anew in Judge Weick's dissent in Detroit, Nos. $72.1809-72-1814$ at 104-07 (6th Cir. June 12, 1973).

70 . In a predecessor of the three primary cases considered in this Note, United States v. Texas, 321 F. Supp. 1043 (E.D. Tex. 1970), 330 F. Supp. 235 (E.D. Tex.), aff'd in part, modified and remanded, 447 F.2d 441 (5th Cir. 197I), cert. denied sub nom. Edgar v. United States, 404 U.S. 1016 (1972), the court found that the state had maintained segre. gation by establishment and maintenance of a number of black school divisions. To remedy the violation the district court required that each black district be annexed to or consolidated with a nearby district to achicve desegregation. 330 F. Supp. at 238. See also Lee v. Macon County Bd. of Educ., 207 F. Supp. 458 (M.D. Ala.), aff'd sub nom. Wallace v. United States, 389 U.S. 215 (1967).

71. See Green v. County School Bd., 391 U.S. 430, 437-38 (1968).

72. Without the state as defendant, the remedy of consolidation could conceivably be limited to cases where there was a finding of collusion between the districts to establish and maintain the boundaries.

The Sixth Circuit panel in its vacated opinion recognized that it was not necessary in fashioning an equitable decree for the district court to find discriminatory conduct on the part of each school district as a prerequisite to including such district in a deregregation area to be defined by the court's decree. Detroit, Nos.72-1809-72-1814 at 68 (6th Cir. Dec. 8, 1972). This point, however, does not appear in the en banc opinion. Detroit, Nos. 72-1809-72-1814 (6th Cir. June 12, 1973). 


\section{The Remedy of Boundary Alteration}

Judicial remedial power in cases involving racial discrimination is guided by the traditional attributes of equity. ${ }^{73}$ These attributes include practicality and flexibility, ${ }^{74}$ and are not limited to restoration of the status quo ante. ${ }^{75}$ The Supreme Court, however, in Swann $v$. Charlotte-Mecklenburg Board of Education, while specifically approving the remedial altering of school district and attendance zones as an interim technique to accomplish school desegregation, cautioned that the remedial judicial authority does not put judges in the shoes of school authorities whose powers are plenary. ${ }^{76}$

The delineation of these competing considerations bearing on the scope of relief has emerged slowly. Early cases dealt with dual schools within a single district. ${ }^{7 \pi}$ More recently the Supreme Court has condemned the carving of two districts out of a single one during the desegregation process. ${ }^{78}$ The distinguishing aspect of the consolidation cases is the fact that the district boundaries are typically long-standing $^{79}$ and coincident with political boundaries. ${ }^{80}$ Additionally, the concern with boundaries arose in the consolidation cases at the remedial stage of litigation, for the initial concern was with the desegregation of the central city schools. Only when city-bound remedies proved ineffective did the courts and the parties widen their focus to include suburban areas and the state school officials. In Wright $v$. Council of the City of Emporia ${ }^{81}$ and United States v. Scotland Neck Board of Education ${ }^{82}$ the Court prohibited state and local officials from creating a new school district from an existing district ${ }^{83}$ because the effect of the boundary alteration was detrimental to the process of desegregation. Emporia marks the first time that the Supreme Court

73. Brown $I I, 349$ U.S. 294, 300 (1955).

74. See Pomeroy's Equity JuRisirudence \$ 109 (5th ed. 1941).

75. Ford Motor Co. v. United States, 405 U.S. 562,573 n.8 (1972). See also Nlcxander v. Hillman, 296 U.S. 222 (1935).

76. Swann v. Charlotte-Mecklenburg Bd. of Educ., 402 U.S. 1, 16, 27 (1971).

77. For a general overview of early school desegregation cases, see generally 13. Musk, supra note 54, at 1.209; Bickel, The Decade of School Desegregation, Progress and Prospects, 64 Colun. L. Rev. 193 (1964); Pollack, Ten Years After, 24 FED. B.J. 123 (1964). 78. Wright v. Council of City of Emporia, 407 U.S. 451 (1972); Unitcd States v. Scot. land Neck City Bd. of Educ., 407 U.S. 484 (1972).

79. In Richmond, however, the boundaries had been altered as recently as 1970, when the city annexed a portion of Chesterfield County. Richmond, $338 \mathrm{~F}$. Supp. at 76.

80. Indianapolis differs from Richmond and Detroit in this regard. In Indianapolis the city itself extended its boundaries and consolidated with Marion County, but the school district or "school city" was restricted to its previously existing boundaries.
Indianapolis, 332 F. Supp. at 675.76.

81. 407 U.S. 451 (1972).

82. 407 U.S. 484 (1972).

83. 407 U.S. at 453 . 
considered the "effect" 84 of school district boundaries, albeit only proposed boundaries, between independent political subdivisions. ${ }^{85}$ The "effect" test originated primarily in Green v. Counly School Board" where the Court endorsed the principle that the remedy should "so far as possible eliminate the discriminatory effects of the past as well as bar like discrimination in the future."

In justifying the alteration of school division boundaries, the district judges in Richmond ${ }^{88}$ and Detroil ${ }^{89}$ placed considerable emphasis on Reynolds v. Sims ${ }^{90}$ and Gomillion v. Lightfoot..$^{01}$

In Reynolds the Supreme Court discussed the instrumentality theory of relationship between the state and its political subdivisions. ${ }^{02}$ The case stands for the proposition that a court can properly take action to require a state, or an agency of a state, to alter district lines, including those coincident with political subdivisions, when such action is required to remedy deprivation of equal protection.

Gomillion also bears directly on boundary alteration. The Court, dealing with gerrymandering of boundaries in Tuskegee, Alabama, relied explicitly on the instrumentality theory and held that a state's right to control its municipalities, and their boundaries, is circumscribed by the limitations imposed by the Constitution. ${ }^{93}$

In fact, the reapportionment cases provide precedent quite similar in scope to the consolidation cases. In Reynolds the Court approved the district court's interim implementation of its own reapportionment plan pending submission and approval of a legislatively-devised plan. ${ }^{94}$ The Sixth Circuit in Detroit also emphasized the legislative role, placing primary responsibility on the Michigan legislature.

84. Id. at 462 .

85. At the time of the court challenge, Emporia had become a "city of the second class" which was "politically independent from the surrounding county .... Id. at 4 J4.

86. 391 U.S. 430 (1968).

87. Id. at 438 n.4, quoting Louisiana v. United States, 380 U.S. 145, 154 (1965).

88. Richmond, 338 F. Supp. 67, 102-03.

89. Detroit, Ruling on Propriety of Considering a Metropolitan Remedy to . Iecomplish Desegregation of the Public Schools of the City of Detroit, Civil Action Xio. 35257 at 2.3 (E.D. Mich. Mar. 24, 1972), vacated, Nos. 72-1809-72-1814 (6th Cir. June 12, 1973).

90. 377 U.S. 533 (1964).

91. 364 U.S. 339 (1960). Gomillion is not wholly apposite, however, since it was decided solely on the basis of the Fifteenth Amendment, rather than the Equal Protection Clause. Id. at 345. See also id. at 349 (Whittaker, J., concurring).

92. Political subdivisions of States-counties, cities, or whatever-never were and never have been considered as sovereign entities. Rather they have been traditionally regarded as subordinate governmental instrumentalities created by the State to assist in the carrying out of state governmental functions.

377 U.S. at 575 .

93. Gomillion v. Lightfoot, 364 U.S. 339, 344-45 (1960). The most recent reapportionment decision, Mahan v. Howell, $93 \mathrm{~S}$. Ct. 979 (1973), does not alter the previously-declared
remedial power of the Court. Id. at 985 .

94. 377 U.S. at 586. 
Nevertheless it directed the district court to fashion a remedy if the legislature failed to act, or acted in a manner inconsistent with eflicient elimination of the constitutional violations. ${ }^{05}$ The Richmond district court, by contrast, ordered implementation of a desegregation plan developed and submitted by the Richmond School Board.90

Although the legislative reapportionment cases do not provide an exact parallel to metropolitan consolidation, they do indicate that the instrumentality theory has been utilized in the Fourteenth Amend. ment context. Moreover they emphasize that a state may be required to restructure its political subdivision boundaries if such action is necessary to eliminate a constitutional violation.

The Fourteenth Amendment, as interpreted and applied in the reapportionment cases, does not require statewide elections for all offices. Similarly, it does not require a uniform racial ratio in all public schools within a state ${ }^{0 t}$ nor statewide administration of public schools. Individual school districts are constitutionally permissible, as long as their maintenance does not perpetuate illegal segregation. However, if school district consolidation is to become a tool for elimination of the vestiges of segregation, its limitations must be understood.

The minimum requirement of a remedial decree is that it include "whatever steps might be necessary" to totally eliminate all vestiges of a segregated system. ${ }^{08}$ Determination of the actual scope of the decree will turn on the standard of "effectiveness" by which any school desegregation plan must be measured.90 The remedy must be effective in eliminating discrimination and effective in fostering quality education. The former standard requires an area large enough to meet its requirement; the latter requires that the area be of manageable size.

A possible index of the optimal size is pupil transportation time. ${ }^{100}$ This index produces a better indication of effectiveness than geographic size by taking into account such factors as decentralized sub. divisions, ${ }^{101}$ transportation routes, and expressways. The district judge

95. Detroit, Nos. 72-1809-72-1814 at 68 (6th Cir. June 12, 1973).

96. The Richmond metropolitan plan was prepared under the supervision of the as. sociate superintendent of the Richmond public school system, Richmond, $338 \mathrm{~F}$. Supp. at 186 , and was the only plan before the district court. Id. at 191 .

97. Swann v. Charlotte-Mecklenburg Bd. of Educ., 402 U.S. 1, 31.32 (1971).

98. Green v. County School Bd., 391 U.S. $430,437.38$ (1968).

99. See, e.g., Davis v. Board of School Comm'rs, 402 U.S. 33, 37 (1971), cited in Wright v. Council of City of Emporia, 407 U.S. 451, 462 (1972).

100. The Richmond district court pointed out that the maximum pupil transportation time under the metropolitan plan would not exceed the currently allowable maximums in the three affected divisions. Richmond, $338 \mathrm{~F}$. Supp. at 188. See the discussion of timc and distance limits in Swann v. Charlotte-Mecklenburg Bd. of Educ., 402 U.S. at 90.31 .

101. The Richmond metropolitan plan divided the consolidated area into six sub. divisions, roughly resembling spokes of a wheel emanating from the center of the city. 338 F. Supp. at 191 . 
in Richmond utilized another standard which is certainly pertinent in determining the consolidation area, that of interdependence and community of interest between the school divisions. His extensive findings of interdependence and basic unity were highlighted by the finding that the racial proportions of the total pupil population in the consolidation area had remained unchanged for ten years despite dramatic changes in the racial composition of the pupil population in the city. ${ }^{102}$

Metropolitan consolidation is certainly not a panacea for the ills of segregated education. In the area of consolidation, probably more than in any other area in the desegregation process, the requirement of a finding of de jure segregation has imposed tremendous strain on the judiciary. Although metropolitan consolidation makes great strides toward dealing with the problem of remedy, it has no bearing upon the issue of de jure versus de facto segregation which contributes greatly to a disparity of results in areas of similar racial composition. Additionally, the remedy acts only peripherally on such problems as the increasing proliferation of segregationist private academies. ${ }^{103}$ Moreover, the courts, as the branch of government with the smallest popular base of support, are particularly illadapted to structure and enforce far-reaching social science solutions to societal problems, particularly when the social sciences lead to indeterminant results. ${ }^{104}$ In this regard, the Sixth Circuit opinion in Detroit, which placed primary responsibility for the elimination of the constitutional violations upon the state legislature, ${ }^{105}$ makes the most effective bid for popular support.

Despite the theoretical and practical considerations which necessarily influence the fashioning of judicial decrees, constitutional principles do not depend upon sociological underpinnings for their stand-

102. Id. at 178-79, 185. See note 17 supra.

103. See Note, Segregation Academies and State Action, 82 YALE L.J. 1436 (1973).

104. The Coleman Report, J. Coleman, et AL., Equaliry of Enucition Oriontusit: (HEW 1966), has stimulated a multitude of views on the role of education in remedying social problems. See, e.g., U.S. CoMmission oN Civit RIGITS, REIORT oN Ricial Isolition in the Public Schools (1967); C. JeNcks, M. SMith, H. ACland, M. Bane, D. Cones, H.

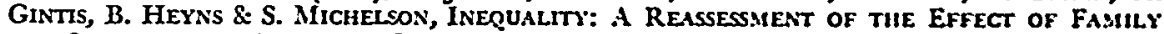
and Schooling in America (1972); ON Equaliti of Educational Oppontunity (F. Mlos. teller \& D. Moynihan eds. 1972); Armor, The Evidence on Busing, 28 THE PUnLIC INTERst 90 (1969).

105. This opinion heretofore has emphasized that the Legislature of Michigan has an opportunity to determine the organizational and governmental structure of an enlarged desegregation area to remedy the unconstitutional segregation results set forth in this opinion. In the event the Legislature fails to act effectively and expeditiously, the foregoing and other cases cited in this opinion outline the broad scope of equitable relief that may be fashioned by the District Court in this case on remand ....

Detroit, Nos. 72-1809-72-1814 at 79-80 (Gth Cir. June 12, 1973). See also id. at 68. 
ing. The principle remains that constitutional violations call for remedial response, and that the remedy must eliminate the violation.

\section{Pupil Exchange: A Possible Middle Ground}

Metropolitan consolidation has often been viewed as an all or noth. ing proposition. This is perhaps unfortunate and to some extent shortsighted. In Richmond, the only case to date ordering implementation of a comprehensive consolidation plan, the court merely approved and ordered implementation of the only plan which it had before it. ${ }^{100}$ The district judge, however, explicitly indicated his willingness to entertain motions for changes in the plan. ${ }^{107}$

Once the constitutional violations have been established, and the responsibility of the state in formulating relief recognized, the relief itself is flexible. Indeed, virtually any remedy that results in eliminating the violation is acceptable. In this regard, the pupil exchanges between city and suburban areas ${ }^{108}$ or even partial consolidation or annexation are possibilities.

\section{Conclusion}

The metropolitan consolidation cases which will follow Richmond require that the courts address the issues left unresolved there. When the inquiry is focused on the state board of education, armed as it is with plenary powers over education in the state, it becomes clear that remedial powers are not bounded by local school division lines. Moreover, local political entities are mere instrumentalities of the state. The duty and obligation to remedy constitutional violations rests where the Fourteenth Amendment places it: upon the state.

106. Richmond, 338 F. Supp. at 191.

107. Id. at 230 .

108. Such exchanges have been used in both Richmond and Detroit in the past. Sce p. 1685 supra. 